\title{
Evaluation of the suitability of synthetic polymer fuels in self-ignition engines
}

The article presents a method for determining the quality of spraying a mixture of oil and synthetic fuels obtained from the processing of polymer materials. Laboratory tests of physical parameters of such a mixture were carried out, which made it possible to determine the limit values for the volume fraction of synthetic fuels. The method of determining the suitability of this type of fuel takes into account the criterion numbers Re and Oh, which include physical parameters such as viscosity, density, and surface tension. The experimental part concerning the distribution of droplets of injected fuel and determination of Sauter Mean Diameter using laser diffraction confirmed the usefulness of the developed method for the assessment of the possibility of using a mixture of petroleum-based and synthetic fuels in self-ignition engines.

Key words: synthetic polymer fuels, Sauter mean diameter, diesel engines

\section{Introduction}

The national environmental policy and international commitments of Poland should ensure sustainable development and usage of resources that would meet the needs of present and future generations. One of the greatest challenges of our time is the progressive depletion of conventional fuels (oil and gas). Another, but also very important, topic is the growing amount of municipal waste of which the largest amount is waste of polymer materials. The management of this type of waste is an increasing issue threatening the ecosystem. $75 \%$ of plastic waste is landfilled or "ends" directly in the environment, including 8 million tons a year in the seas and oceans. Even in the European Union, where the most rigorous regulations apply, less than $32 \%$ is recycled while the remaining waste is incinerated, stored or exported. Cities and towns around the world need processes to stop the plastic waste stream from being directed to garbage dumps and incinerators. The combustion process is very capital intensive and is one of the most expensive methods of producing energy and eliminating waste. Compared to the recycling process, the incineration of plastics generates almost three times more greenhouse gas emissions and recovers only $20 \%$ of the energy contained in polymeric materials [28].

Considering the polymer materials' types and methods of their use, there is no single and simple solution to all the problems related to the waste management. However, one possible direction of the use is a chemical recycling which is associated with the production of liquid alternative fuels. It should be emphasized that, according to the Directive 2014/94/EU of $22^{\text {nd }}$ October 2014 on the deployment of alternative fuels infrastructure, "alternative fuels" means fuels or power sources which serve, at least partly, as a substitute for fossil oil sources in the energy supply to transport and which have the potential to contribute to its decarbonization and enhance the environmental performance of the transport sector. They include, inter alia electricity, hydrogen, biofuels, synthetic and paraffinic fuels, natural gas [6].

Up-to-day, scientific and research works on alternative fuels has focused on the use of biofuels based on oil plants.
During almost all Congresses and Scientific Conferences in Poland and abroad (CIMAC, KONMOT, PTNSS, KONSPAL, KONES, OMiU, and others) there was presented and discussed the information on the use of rapeseed or sunflower oil methyl esters and other plant oils. However, there has been no presentation or debate on the research results referring to the usage of synthetic fuels generated from municipal waste or their mixture with petroleum-based fuels. No comprehensive assessment of their use in selfignition engines has also been presented. And hence, this paper covers the topic mentioned above.

\section{Conversion of plastic waste to liquid fuel - technologies}

The history of waste polymers processing into fuel fractions in Poland dates back to the end of the 20th century. Technologies originate from carbochemistry covering a detailed analysis of the chemical processing of fossil coal by gasification and liquefaction [24].

Coal liquefaction process was applied during the Second World War to produce synthetic gasoline [24]. In the formal sense, coal is a cross-linked polymer with a complex structure and poor quality. Transferring the processes from coal processing to plastic waste treatment is relatively simple. However, technical problems may be encountered as result of a highly diverse chemical structure of this group of waste. The thermoplastic properties of same are responsible for problems in technological processes at higher temperatures [3, 18].

The technologies are intended to recover energy from waste materials, including non-biodegradable, such as biomass, municipal solid waste, agricultural waste and highenergy-density materials (rubber and polymers). Polymeric materials are non-biodegradable polymers that contain carbon, hydrogen and other elements (chlorine, nitrogen, etc.) $[15,17,28]$.

The methodologies for polymer waste processing into liquid fuels include:

- Pyrolysis - the main factor causing the polymers' decomposition is the temperature which usual range is from $523 \mathrm{~K}$ to $773 \mathrm{~K}$. The main assumption for the process is the total absence of oxygen. If the oxygen is present, the reactants' oxida- 
tion would occur and it would become a semi-burning or burning process. What is also important in this particular part is that the pyrolysis process does not involve reaction with catalysts, but often it is carried out in the presence of water. In order to ensure that the pyrolysis process is run correctly, a low pressure, not exceeding 0.2 MPa, is a prerequisite. The hydrocarbon pyrolysis process may be described by the following simplified chemical equation [22]:

$$
\begin{gathered}
\mathrm{C}_{\mathrm{x}} \mathrm{H}_{\mathrm{y}} \mathrm{O}_{\mathrm{z}}+\text { thermal energy }+\mathrm{CO}_{2}+\mathrm{H}_{2} \mathrm{O}=\mathrm{CO}+\mathrm{CH}_{4}+\mathrm{C}_{2} \mathrm{H}_{6} \\
+\mathrm{CH}_{2} \mathrm{O}+\ldots+\mathrm{C}_{\mathrm{m}} \mathrm{H}_{\mathrm{n}}+\mathrm{C}_{-\mathrm{q}}
\end{gathered}
$$

Among the pyrolysis products, the liquid phase is the major one (its share equals ca. $60 \%$ regardless of the pyrolysis temperature). As the temperature rises, the amount of solid phase decreases in favour of the gas phase [16]:

- Catalytic cracking - the factor leading to the degradation of polymer macromolecules is a suitable catalyst. The course of the catalytic cracking process is similar to the pyrolysis one. As a result of pyrolysis, products of lower molecular weight are obtained (as in catalytic cracking). However, they consist of a whole range of saturated and unsaturated organic compounds, and the process requires a higher temperature. Due to the catalyst, the temperature of the cracking process may be lowered, as well as a much more favourable composition of products may be obtained.

- Catalytic depolymerization - in the catalytic depolymerisation technology (KDV), the key parts are the friction turbine and the catalyst composition. The hydrocarbon molecules of the input material are broken down by the catalyst in the oil suspension cycle at a temperature of 553-615 K. The generated diesel vapor is separated in the distillation column. The main advantages of the KDV process include low process temperature (about $553 \mathrm{~K}$ ), the high processing efficiency of $80 \%$, high energy efficiency (only about $10 \%$ of the fuel produced in it is consumed for own use), low amount of waste and contamination emitted to the environment;

- Thermolysis supported by hydrogenation and izomerization - plastic waste is provided to the reactor where the cracking process takes place. Reactive distillation occurs and sufficiently long-chain hydrocarbons are obtained. Vapors from the reactor are provided directly to the non-pressurized hydrogenation reactor, followed by isomerization. Hydrogenation and izomerization are the second stage of the entire process, which distinguishes it from other such technologies. The process is carried out in a synthesis gas atmosphere, i.e. a mixture of carbon monoxide and hydrogen.

For the purpose of further studies, the authors have decided to apply a conversion technology such as the catalytic depolymerization of synthetic fuel generated from municipal waste. The decision has been made based on the fact that the process is currently the most popularized and the implementation cost is relatively low.

\section{Analysis of processes in a combustion chamber of self-ignition engines}

A feasibility assessment regarding the use of synthetic fuels or their mixture with petroleum-based fuels in selfignition engines requires a detailed analysis of the processes occurring in the combustion chamber of these engines. The thermodynamic analysis of the engine's thermal cycle shows that the efficiency of using heat during combustion in a given engine is determined by its location in time [23]. It would be the most optimal from this point of view to combust the entire amount of fuel at a constant volume of the combustion chamber when the piston is at the top dead centre (TDC). However, then the rate of heat evolution would become excessively large causing the impact loads on the crank mechanism and acoustic symptoms in the form of excessive loudness [25]. Therefore, the process of heat release is extended and it covers a specific rotation angle of the crankshaft near TDC. The conditions of efficient heat release and its application, obtaining reduced dynamic loads of the crank mechanism along with the silent-running at the possible lowest level are opposed and any technical solution to this matter shall constitute a compromise [11]. An additional factor hindering this compromise is the content of the exhaust gas, which shall meet certain requirements. Experience shows that satisfactory results for a given engine, both in terms of the crank mechanism loads, engine noise level, exhaust gas composition and cost efficiency of its operation, are extremely difficult to obtain, and the optimal solution may be usually applied only when the course of heat evolution is strictly-defined. Consequently, the entire process shall not be spontaneous, uncontrollable. Therefore, the most important matter related to the selfignition engine operation is such combustion management that the physical and chemical effects of this process corresponded to the various requirements for engine use $[2,21]$.

The abovementioned physical and chemical processes may be presented by the following stages - fuel pumping, atomizing, fuel break down into droplets and their evaporation, combustible mixture formation, ignition delay, combustion and heat release.

In the processes prior to the self-ignition, a certain amount of the chemical compounds of fuel and oxygen molecules was found to be torn apart [7]. While the self-ignition process itself takes place in the gas phase. Therefore, in the process of fuel self-ignition, it is essential that fuel evaporates and is mixed with air in the proper proportions. The second condition is met automatically since in the fuel jet area there is a variable concentration of fuel vapours, from a very poor mixture (on the stream periphery) to a very rich one (in the stream core). In order to evaporate the fuel, a certain amount of thermal energy is required. In the selfignition process, it is significant to transfer the energy from the heated air to atomized fuel droplets. By adopting the appropriate simplification, one may assume that this process takes place under fixed conditions. Therefore, in order to describe the process, the heat transfer equation may be applied in the form of the Newton equation [4, 27]:

$$
\tau=Q_{\mathrm{n}} /\left(\mathrm{t}_{\mathrm{C}}-\mathrm{t}_{\mathrm{f}}\right) \mathrm{F}
$$

where: $Q_{n}$ - heat necessary to evaporate an amount of fuel that is essential to generate a mixture with air for ignition $[\mathrm{J}], \mathrm{t}_{\mathrm{C}}$ - average air temperature in ignition delay period $\left[{ }^{\circ} \mathrm{C}\right], \mathrm{t}_{\mathrm{f}}$ - injected fuel temperature $\left[{ }^{\circ} \mathrm{C}\right], \alpha$ - heat transfer coefficient $\left[\mathrm{W} / \mathrm{m}^{2} \mathrm{~K}\right], \mathrm{F}-$ atomized fuel surface $\left[\mathrm{m}^{2}\right], \tau-$ ignition delay period.

The $Q_{n}$ value is subject to a fuel type. If the fuel contains a large amount of paraffin fractions, the value of $Q_{n}$ is low, 
while for fuel with a large number of aromatic hydrocarbons, the value of $Q_{n}$ is higher. The explanation may be that aromatic hydrocarbon particles have greater durability of interatomic connections [1]. When analyzing $\mathrm{t}_{\mathrm{C}}$ and $\mathrm{t}_{\mathrm{pal}}$, one may note that they are subject to the engine structural parameters (e.g. compression ratio), ambient parameters and in this case, the comparison of various fuel types may be omitted. This also refers to the heat transfer coefficient. However, F shall be analyzed in detail. This is due to the fact that the atomized fuel stream consists of concentrated smallest drops, and their number and diameter directly affect the parameter $\mathrm{F}$, which sequentially has an impact on the processes of evaporation and mixing of fuel vapors with air.

As the main criterion for the liquid atomization process quality, the droplet diameter in the atomized jet is given [5, 7]. As the defined dose of fuel is atomized, its surface area is enlarged and thus the amount of absorbed heat, due to which fuel vaporizes, increases. Simultaneously, the droplet diameter affects the jet macrostructure i.e. the atomization angle and the spray tip penetration as well as the parameters impacting the accuracy of mixing with air, optionally for gathering fuel droplets on the cylinder walls or the piston bottom. The conclusion is that the droplet diameter in the spray is a compromise between the largest possible fuel surface (the shortest droplet diameter) and the spray range in the combustion chamber. The differences between requirements for individual engines may result, among others, from working process management (combustion chamber structure). Unlike chambers with direct injection, in divided or vortex combustion chambers, droplet diameters may be larger and the length of spray may be shorter due to the intense and dynamic mixing process with air.

The quality of fuel atomization process is evaluated on the basis of its accuracy (droplet diameter) and homogeneity (number of droplets of the same diameter), using the average droplet diameter. They have been established as conventional values and they describe a set of homogeneous droplets as a substitute of the actual set (atomization spectrum). Depending on the methodology and the calculation method, the average droplets' diameter may determine such values as number, diameter, area, and volume of droplets. The adoption of an average diameter is subject to the field of application of the atomized liquid and although it does not provide any information on the droplet set itself, it is considered as the most demonstrative quantity for assessing the quality.

Regardless of how the working process in the engine is organized and managed, the following processes take place in the combustion chamber: droplets' vaporization, heat transfer, and exchange, fuel combustion. Therefore, for the quality assessment purpose, the Sauter mean diameter $\left(D_{32}\right.$ or SMD) is implemented. It is also the relation of the droplet volume to its surface in the actual and theoretical spray.

In the literature, regarding the subject of research $[8,13$, $14,26]$ there are formulas available that allow calculating $\mathrm{D}_{32}$. They differ in the number of considered physical parameters, constant values, and exponents. In general, these relationships may be presented as follows:

$$
\operatorname{SMD}=\mathrm{f}(\mu, \rho, \sigma, \Delta \mathrm{P}, \mathrm{k})
$$

where: $\mu, \rho, \sigma-$ dynamic viscosity, density and surface tension of fuel, $\Delta \mathrm{P}-$ the pressure difference between the pressure of injected fuel and the medium pressure to which it is injected, $\mathrm{k}$ - includes structural parameters of the atomizer. It should be highlighted that the majority of the above parameters are physical fuel parameters that are indirectly or directly included in the Reynolds number, Laplace number, Ohnesorge number [12, 19].

The literature analysis indicates that the stream breakdown mechanism may be presented in four stages [14] viscous flow, transient flow, turbulent flow, and specific atomization. The mechanism has been illustrated by the Ohnesorge diagram where the abovementioned stages are presented. Summing up, the assessment of the suitability of synthetic fuels for self-ignition engines, as an additional feature, may answer the question whether the physical parameters of the fuel or a mixture of this fuel with diesel meet the conditions specified in the Ohnesorge diagram as the specific atomization.

\section{Laboratory tests of physical parameters and quality of fuel mixture atomization process}

The first stage of tests was performed at the Centre for Fuel and Hydraulic Fluids Testing and Environmental Protection of the Maritime University of Szczecin and at the engine laboratory of the Motor Transport Institute of Warsaw. During that stage, the physical and chemical parameters of the synthetic fuel were determined as well as its mixtures with diesel fuel.

The synthetic fuel equaled to $3,5,7,20 \%$ (by volume) to petroleum-based fuel and $100 \%$ of synthetic fuel. It was noted that the value of $7 \%$ synthetic fuel additive is the threshold for the minimum ignition temperature (according to PN-EN590), lower values of the volume of synthetic fuel additives meet the standard requirements (Fig. 1). However, other physical parameters for both $100 \%$ synthetic fuels and mixtures with petroleum diesel meet the requirements imposed by PN-EN590 (Table 1).

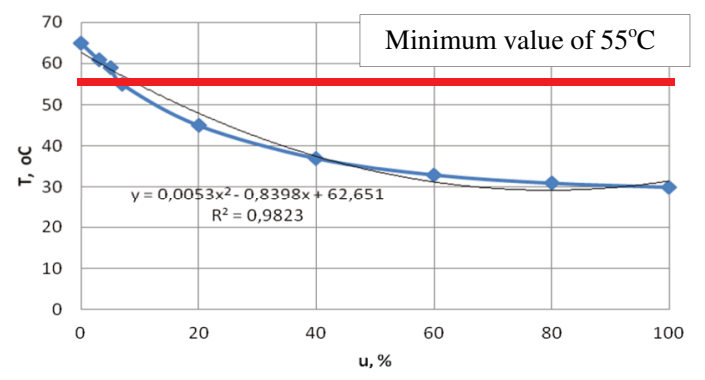

Fig. 1. Relationship between content of synthetic fuel in the fuel mixture (u) and flash point [20]

The second stage included the laboratory tests the aim of which was to determine the quality of the atomized fuels. The volume of synthetic fuels in the mixture was limited to $7 \%$ due to the ignition temperature of the mixture. As a result of the high accuracy of the outcomes and relatively simple operation of the device used for the research, the laser diffraction method has been selected $[10,12,25]$. This method is based on the measurement of the scattering of the He-Ne laser beam. The Spraytec device of Malvern has been used 
for that task (Fig. 2a) with 30 receiver's detectors. They detect scattered light on the stream particles and convert it into an electrical signal. For the laboratory tests purpose, D1LMK148/1 atomizer has been used. The selection of this type of atomizer was driven by the fact that it has three atomization holes. Due to that one of the stream maybe straightforwardly directed into the laser area. Two remaining jets may be directed to properly set traps (Fig. 2b).

Table 1. Physical parameters of selected fuels

\begin{tabular}{|l|l|c|c|}
\hline & & $\begin{array}{c}\text { Acc. To PN-EN } \\
\text { 590+A1:2011 }\end{array}$ & $\begin{array}{l}\text { Results } \\
\text { ON+7\%PP }\end{array}$ \\
\cline { 3 - 4 } & & ON “standard" & \\
\hline Kinematic viscosity at & Min. & 2.00 & 2.6 \\
$40^{\circ} \mathrm{C}, \mathrm{mm}^{2} / \mathrm{s}$ & Max. & 4.50 & 830 \\
\hline Density at $15^{\circ} \mathrm{C}, \mathrm{kg} / \mathrm{m}^{3}$ & Min. & 820.00 & 57 \\
& Max. & 845.00 & 55 \\
\hline Cetane number & Min. & 51.0 & 26,40 \\
\hline Flash point ${ }^{\circ} \mathrm{C}$ & Min. & 55 & 0.08 \\
\hline Surface tension $\mathrm{J} / \mathrm{m}^{2}$ & & 26,08 & \\
\hline Remains after high tem- & Max & 0.30 & 355 \\
perature carbonization, & & & \\
MCR at $10 \%$ residue, $\%$ & & & \\
mass & & & \\
\hline Lubricity, wear scar diam- \\
eter (wsd 1.4 ) at $60^{\circ} \mathrm{C}, \mu \mathrm{m}$
\end{tabular}
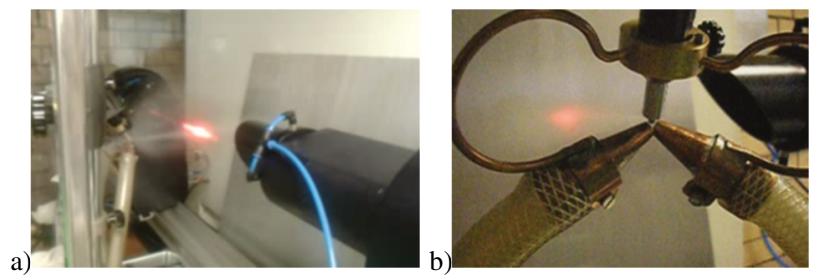

Fig. 2. Laboratory stand for testing the quality of fuel atomization (a) and D1LMK148/1 atomizer (b)

In the case of an atomized fuel stream consisting of a large number of drops of various diameters, the measurement of their size distribution is hampered by multiple scattering. Therefore, the Spraytec software uses a multiple scattering algorithm which includes background factors (electronic, optical) and light scattering components [9]. Moreover, the Spraytec software computes the particle size distribution in aerosols by comparing the measured scattering spectrum with an optical model. The main result of the measurements is the calculation of the mean droplet diameter (Sauter mean diameter). Figure 3 presents the examples of droplet diameters for a mixture of petroleum-based fuel with the addition of $7 \%$ synthetic fuel. Whereas, Figure 4 demonstrates the results of laboratory tests showing the relation between the Sauter mean diameter and the fuel mixture.

The SMD values, calculated as per the above, have been compared with the values computed based on the formulas presented in the scientific literature [2] including the physical parameters of fuel mixtures (Table 1). The most similar nature of these relations was obtained when the Elkobt equation had been applied (Fig. 4).

The difference between the results obtained experimentally and the values calculated using Elkotb equation may be corrected by the following polynomial relation:

$$
f(x)=0.475 x^{2}-1.431 x-6.765
$$

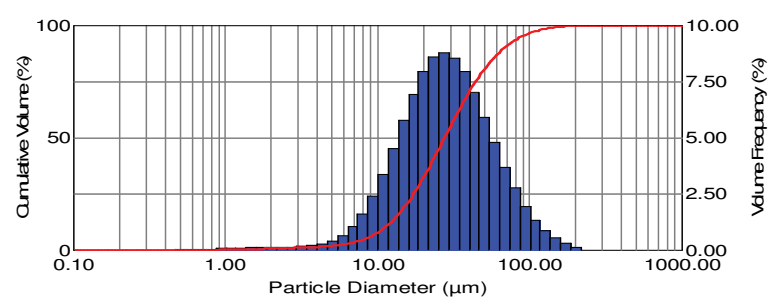

\begin{tabular}{|cc|}
\hline $\operatorname{Dv}(10)=12,26(\mu \mathrm{m})$ & Span $=2,438$ \\
$\operatorname{Dv}(50)=29,18(\mu \mathrm{m})$ & $\mathrm{D}[3][2]=25,02(\mu \mathrm{m})$ \\
$\operatorname{Dv}(90)=83,39((\mu \mathrm{m})$ & $\mathrm{D}[4][3]=49,17(\mu \mathrm{m})$ \\
\hline
\end{tabular}

Fig. 3. Atomization spectrum and total distribution of diesel droplets with the addition of $7 \%$ synthetic fuel

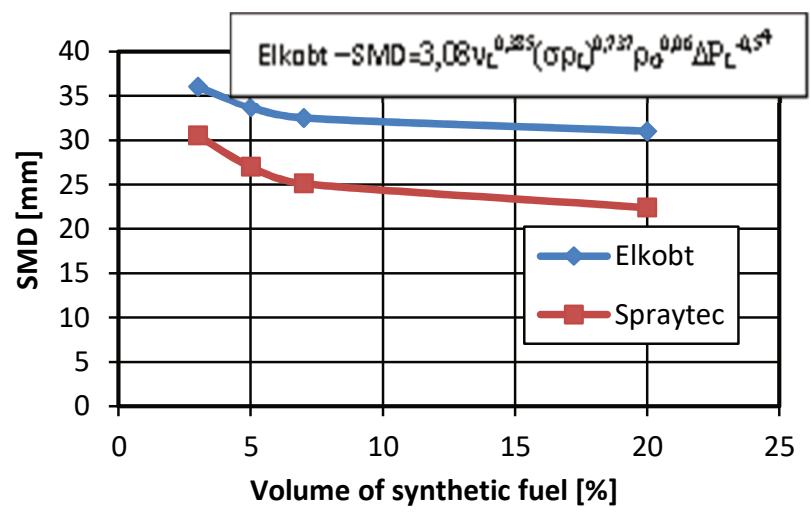

Fig. 4. SMD values calculated using Elkotb equation compared to SMD values obtained by Spraytec

In the above relations, the correlation coefficient $\mathrm{R}^{2}$ equals to 0.9713 ( $\mathrm{x}$ - determines the volume fraction of synthetic fuel in a mixture with petroleum diesel). A standardized formula for SMD of the mixture may be presented as follows:

$$
\operatorname{SMD}=\mathrm{f}(\mathrm{x}) \cdot 3.08 \mathrm{v}_{\mathrm{L}}^{0.385}\left(\sigma \rho_{\mathrm{L}}\right)^{0.737} \rho_{\mathrm{G}}^{0.06} \Delta \mathrm{P}_{\mathrm{L}}^{-0.54}
$$

where: $v_{\mathrm{L}}-$ kinematic viscosity of fuel mixture $\left[\mathrm{m}^{2} / \mathrm{s}\right], \rho_{\mathrm{L}}$ - density of fuel mixture $\left[\mathrm{kg} / \mathrm{m}^{3}\right], \sigma-$ surface tension of fuel mixture $[\mathrm{N} / \mathrm{m}], \rho_{\mathrm{G}}-$ density in the gas medium to which fuel mixture is injected $\left[\mathrm{kg} / \mathrm{m}^{3}\right], \Delta \mathrm{P}_{\mathrm{L}}-$ pressure difference between the fuel and the gas medium [Pa].

The significant matter in the relation above (4) is that it includes all physical parameters of the fuel: surface tension, viscosity, density. It confirms the impact of these parameters on the quality of the atomization process.

\section{Method for determining the suitability of synthetic fuels for self-ignition engines by using criterion numbers}

Based on the laboratory tests and the literature analysis, the authors wish to propose a methodology that allows specifying additional features that prove the suitability of synthetic fuels for self-ignition engines.

As mentioned above, fuel atomization process is fundamental for the engine working process management. It may be specified qualitatively by the Sauter mean diameter of the atomized fuel droplets. This parameter, sequentially, is dependent on the fuel physical parameters being a part of the criterion equations (4). For the purpose of this paper, Ohnesorge and Reynolds numbers have been selected along 
with the Ohnesorge diagram in order to present visually the usefulness of synthetic fuel for self-ignition engines.

At the first stage of the analysis, the methodology provides that the following physical parameters of the tested fuel are specified: fuel dynamic or kinematic viscosity, $\eta_{\mathrm{F}}$ or $v_{\mathrm{F}}$ accordingly, fuel density $\rho_{\mathrm{F}}$ and surface tension $\sigma$.

The second stage is related to the determination of the structural parameters of the engine that are directly part of the criterion equations: atomization holes' diameter $\mathrm{d}_{\mathrm{o}}$, fuel injection pressure $\mathrm{p}_{\mathrm{F}}$, rotational speed $\mathrm{n}$, engine compression ratio $\varepsilon$ or pressure $\mathrm{p}_{\mathrm{A}}$ at the end of the compression stroke. If the parameters are not available in the engine technical documentation, they may be calculated based on the literature sources [21].

The next stage is to calculate the criterion numbers' values (Oh and $\mathrm{Re}$ ) as follows:

$$
\mathrm{Oh}=\frac{\eta_{\mathrm{F}}}{\sqrt{\varrho_{\mathrm{F}} \sigma \mathrm{d}_{\mathrm{o}}}}, \quad \mathrm{Re}=\frac{0,6 \sqrt{2 \frac{\mathrm{p}_{\mathrm{F}}-\mathrm{p}_{\mathrm{A}}}{\varrho_{\mathrm{F}}}} \mathrm{d}_{\mathrm{o}} \varrho_{\mathrm{F}}}{\eta_{\mathrm{F}}}
$$

where: $\eta_{F}$ - fuel dynamic viscosity $\eta_{F}=v_{F} \varrho_{F}[\mathrm{~Pa}]$, $v_{F}-$ fuel kinematic viscosity, $\rho_{\mathrm{F}}-$ fuel density $\left[\mathrm{kg} / \mathrm{m}^{3}\right], \sigma-$ surface tension $[\mathrm{N} / \mathrm{m}], \mathrm{d}_{\mathrm{o}}-$ atomization hole diameter $[\mathrm{m}], \mathrm{p}_{\mathrm{F}}-$ fuel pressure $[\mathrm{Pa}], \mathrm{p}_{\mathrm{A}}-$ air pressure $[\mathrm{Pa}]$.

The calculation results shall be plotted on the Ohnesorge diagram. If the values are within the diagram field that corresponds to the specific atomization, the tested fuel upon its injection to the combustion chamber will undergo a specific atomization process. It proves its suitability for self-ignition engines.

An example of how to apply the methodology for the petroleum-based fuel mixed with synthetic polymer fuel is presented in Fig. 5.

The intersection point of $\mathrm{Oh}$ and Re numbers on the Ohnesorge diagram for a mixture of diesel oil and 7\% additives of synthetic polymer fuel is located in the area of atomization. This entitles to determine the suitability of the tested fuel for self-ignition engines.

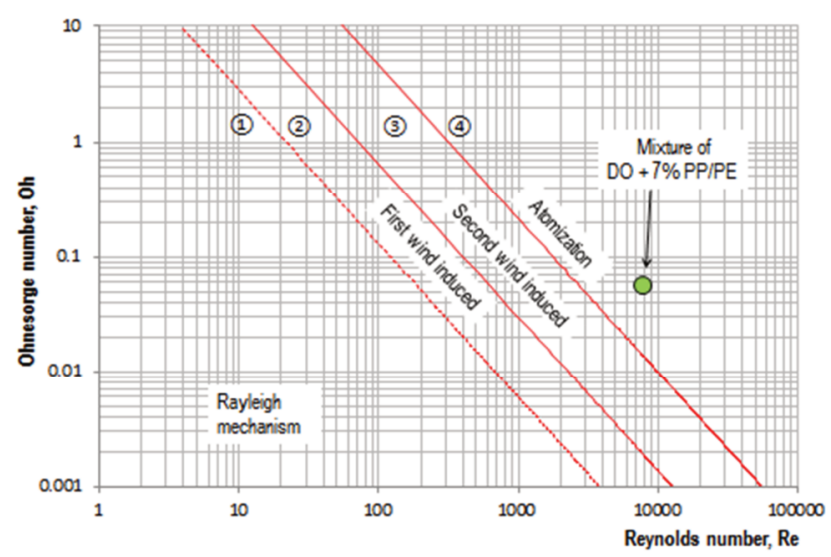

Fig. 5. Graphical presentation of the suitability of the tested fuel in the Ohnesorge diagram

\section{Conclusions}

The conducted analysis of knowledge base, analytical studies and laboratory tests entitle to form and present the following conclusions:
- Plastic waste is a serious problem as it has an adverse impact on the environment and ecosystem. However, the concept of a circular economy, where the environment is affected by the products produced through the selection of raw materials at the minimum level as well as by their respective products, provides for a minimization of the number of resources used and the volume of waste. The variety of polymer materials, their properties and areas of application make it necessary to analyze the methodologies and technologies of their processing and the production of synthetic liquid fuels,

- The most standard and low-cost method for synthetic polymer fuels is a technology where the catalytic depolymerization process is applied;

- The initial stage of feeding the fuel to the combustion chamber involving the atomization of fuel is the key one for further processes such as preparation of fuel and air mixture, its ignition and combustion. At that stage, the fuel disintegrates into droplets, the size of which (and the total surface area resulting from it), with specific parameters of fuel condition and geometrical parameters of the atomizer nozzle, depend on the viscosity and surface tension of the liquid. Atomization process may be presented qualitatively by applying the mean diameter (SMD) parameter of the droplet determined by equations containing primarily the physical parameters of the fuel, which are the components of criterion equations,

- The relation of the $\mathrm{Oh}$ and Re numbers in the Ohnesorge diagram specifies the jet break-up surface areas where one refers to the atomization. The $\mathrm{Oh}$ and $\mathrm{Re}$ values, obtained upon having the actual physical parameters of the fuel applied, are presented as a point on the Ohnesorge diagram. The location of the coordinates of this point in the area of atomization indicates the suitability of the fuel.

- The laboratory tests have shown that almost every physical parameter of both the mixture of synthetic fuel and petroleum-based oils and $100 \%$ synthetic fuel meet the standards for fuels for self-ignition engines. The exception is the ignition temperature of a mixture of petroleum oils and synthetic fuels, which exceeds the ignition temperature allowed by PN. However, it applies to a mixture with more than $7 \%$ synthetic fuel content. The obtained results for ignition temperature corresponding to the $7 \%$ synthetic fuel is in line with the permissible content of additives for petroleum-based fuels as per PN-EN590.

- The obtained results of SMD measurement on a laboratory bench using the laser diffraction method have been compared with SMD values calculated according to the formulas known from the literature of the research subject. The result closest to the outcome of the measurement resulted in the analytical determination of SMD by the application of the Elkobt equation, which may be modified by the use of a polynomial equation.

- A methodology to determine the suitability of tested fuel in self-ignition engines has been developed. The methodology includes the determination of physical fuel parameters, engine structural parameters, calculation of $\mathrm{Oh}$ and $\mathrm{Re}$ criterion values based on the data obtained at the first and second stage of the methodology and introduction of the coordinates of the criterion numbers on the Ohnesorge diagram. The coordinates in the Ohnesorge diagram 
illustrate the point where the presence in the area of atomization proves the suitability of the tested fuel for selfignition engines. The used mixture of petroleum oil and the $7 \%$ addition of synthetic fuel meets this condition.

\section{Acknowledgements}

This research outcome has been achieved under the research project No 1/S/IESO/2014 financed from a subsidy of the Ministry of Science and Higher Education for statutory activities.

\section{Bibliography}

[1] AMBROZIK, A. Wybrane zagadnienia procesów cieplnych w tłokowych silnikach spalinowych, Wydawnictwo Politechniki Świętokrzyskiej. Kielce 2003.

[2] BACZEWSKI, K., KAŁDOŃSKI, T. Paliwa do silników o zapłonie samoczynnym. Wydawnictwa Komunikacji $i$ Laczności. Warszawa 2008.

[3] BALAWENDER, K., JAKUBOWSKI, M., KUSZEWSKI, H. Parametry fizykochemiczne paliwa syntetycznego przeznaczonego do zasilania silników o ZS. Вісник Націо-нального транспортного університету. 2014, 30(1).

[4] CHEN, P-C., WANG, W-C., ROBERTS, W.L., FANG, T. Spray and atomization of diesel fuel and its alternatives from a single-hole injector using a common rail fuel injection system. Fuel. 2013, 103.

[5] FANG, Z., MARCHETTI, J.M. Biodiesel: blends, properties, and applications. Nova Science Publishers 2011.

[6] GRONOWICZ, J. Ochrona środowiska w transporcie lądowym. Wydawnictwo i Zakład Poligrafii Instytutu Technologii i Eksploatacji. Poznań-Radom 2003.

[7] HEYWOOD, J.B. Internal combustion engines fundamentals. McCraw-Hill Book Co. New York 1988.

[8] HIROYASU, H., Diesel engine combustion and its modeling, diagnostics and modeling of combustion in reciprocating engines. COMODIA 85. Proceedings of Symposium. Tokyo 1985.

[9] Instrukcja obsługi analizatora wielkości cząstek Spraytec, Tłumaczenie AP Instruments, wersja 3.0., 2007.

[10] KLYUS, O., ZAMIATINA, N. Residual fuel atomization proces simulation. Combustion Engines. 2017, 169(2).

[11] KOWALEWICZ, A. Podstawy procesów spalania. Wydawnictwa Naukowo-Techniczne PWN-WNT. Warszawa 2000.

[12] KRAUSE, P. Assessment criteria for ignition properties of diesel engine fuels. Problems of Mechanics. 2014, 3(56).

[13] LEFEBVRE, A.H. Atomization and Sprays. Hemisphere Publishing Corporation 1989.

[14] LIU, H. Science and Engineering of Droplets - Fundamentals and Applications, Noyes Publications, Park Ridge, New Jer-

Prof. Oleh Klyus, DSc., DEng., D.h.c. - Faculty of Mechanical Engineering, Maritime University of Szczecin.

e-mail:olegklus@o2.pl

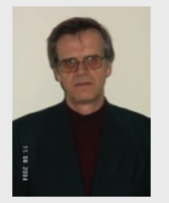

Prof. Vladimir A. Markov, DSc., DEng. - Department of Piston Engines, Bauman Moscow State Technical University, Russian Federation.

e-mail: vladimir.markov58@yandex.ru

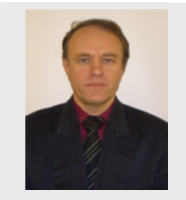

Bowen SA, MEng. - Department of Piston Engines. Bauman Moscow State Technical University, Russian Federation.

e-mail: bowensa@yandex.ru sey, U.S., William Andrew Publishing. LLC Norwich, New York 2000.

[15] LOTKO, W. Studium zastosowań paliw alternatywnych do silników z zapłonem samoczynnym. Politechnika Radomska. Radom 2000.

[16] LUBOWICZ, J. Węglowodory z odpadowych tworzyw sztucznych i biomasy. Nafta-Gaz. 2009, 65, 9 .

[17] MACEIRAS, R., Diesel fuel from plastic waste. Pharmaceutical Analytical Chemistry. 2016, 2.

[18] MĄCZKA, T. Technologia plazmowego zgazowania biomasy i odpadów organicznych dla wytwarzania paliw płynnych. Wydawnictwo Ksiązkowe Instytutu Elektrotechniki. Warszawa 2014.

[19] ORZECHOWSKI, Z., PRYWER, J. Rozpylanie cieczy w urządzeniach energetycznych. Wydawnictwa NaukowoTechniczne. Warszawa 1994.

[20] SKARBEK-ŻABKIN, A. Analiza przydatności paliw syntetycznych polimerowych do zasilania silników o zapłonie samoczynnym. Rozprawa doktorska. Szczecin, 2019.

[21] WAJAND, J.A., WAJAND, J.T. Tłokowe silniki spalinowe, WNT. Warszawa 2005.

[22] WIELGOSIŃSKI, G. Przegląd technologii termicznego przekształcania odpadów. Nowa Energia. 2011, 1.

[23] ZABŁOCKI, M. Wtrysk i spalanie paliwa w silnikach wysokoprężnych. WKit. Warszawa 1976.

[24] ZWIERZYCKI, W. Paliwa silnikowe i oleje opałowe. Rafineria Nafty „Glimar”. 1997.

[25] ВОИНОВ, А.Н. Процессы сгорания в быстроходных поршневых двигателях. М., Машгиз, 1980.

[26] КУЛЕШОВ, А.С. Программа расчета и оптимизации двигателей внутреннего сгорания ДИЗЕЛЬ-РК. Описание математических моделей, решение оптимизационных задач. МГТУим. Н.Э.Баумана. 2004.

[27] СВИРИДОВ, Ю.Б. Топливо и топливоподача автотракторных дизелей. Л, Машиностроение. 1979.

[28] www.handerek-technologies.com 03.2018.

Paweł Krause, DEng. - Faculty of Mechanical Engineering, Maritime University of Szczecin. e-mail:p.krause@am.szczecin.pl

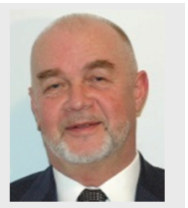

Anna Skarbek-Żabkin, DEng. - Warsaw Motor

Transport Institute.

e-mail: anna.skarbek@its.waw.pl

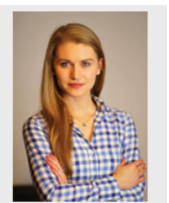

